\title{
Assessment of Drying Characteristics and Texture in Relation with Micromorphological Traits of Carob (Ceratonia silliqua L.) Pods and Seeds
}

\author{
Maja Benković ${ }^{1}$, Siniša Srečec ${ }^{2}$, Ingrid Bauman ${ }^{1 *}$, Damir Ježek ${ }^{1}$, Sven Karlović1, \\ Dario Kremer ${ }^{3}$, Ksenija Karlović ${ }^{4}$ and Renata Erhatić ${ }^{2}$ \\ ${ }^{1}$ University of Zagreb, Faculty of Food Technology and Biotechnology, Pierottijeva 6, \\ HR-10000 Zagreb, Croatia \\ ${ }^{2}$ Križevci College of Agriculture, M. Demerca 1, HR-48260 Križevci, Croatia \\ ${ }^{3}$ University of Zagreb, Faculty of Pharmacy and Biochemistry, Schrottova 39, HR-10000 Zagreb, Croatia \\ ${ }^{4}$ University of Zagreb, Faculty of Agriculture, Svetošimunska 25, HR-10000 Zagreb, Croatia \\ Recieved: October 14, 2015 \\ Accepted: May 13, 2016
}

\begin{abstract}
Summary
Carob tree (Ceratonia siliqua L.) is a perennial leguminous evergreen tree native to the coastal regions of the Mediterranean basin and is considered to be an important component of vegetation for economic and environmental reasons. Two constituents of the pod, pulp and seeds, can be used as feed or in food production. In this study, drying characteristics, texture and microstructure of carob pods were studied. Three different carob samples were prepared: whole carob pod, carob pod parts and carob seed. The drying experiments and the modelling showed that carob seeds had the highest drying rate, followed by pod parts and the whole, intact carob fruit. Texture studies showed that the maximum compression force depended on the area of the carob fruit on which compression tests were performed. The seeds showed the highest compression force, followed by the stem zone, the tip and the centre of the fruit. Differences in drying behaviour and texture of carob pods can successfully be interpreted by the micromorphology of the carob pods and seeds. Determining the drying rate, maximum compressive force and micromorphological traits is of great importance for further carob processing (e.g. milling, sieving, carob bean gum production or usage in food or feed products).
\end{abstract}

Key words: carob, drying, texture, micromorphology

\section{Introduction}

Carob tree (Ceratonia siliqua L.) is a plant belonging to the Fabaceae family (1). It is a perennial leguminous evergreen tree native to the coastal regions of the Mediterranean basin and southwest Asia, and is considered to be an important component of vegetation for economic and environmental reasons (2). In spite of the historical fact that the value of carob tree was recognized by the ancient Greeks and the Arabs, carob has been neglected in both cultural practices and research and development. It has been spread recently to other Mediterranean-like regions such as California, Arizona, Mexico, Chile and Argentina by Spaniards, to parts of Australia by Mediterranean emigrants and to South Africa and India by the English. Even nowadays, carob pods and juice have a very important role in the diet of Mediterranean countries $(3,4)$. During the 1990s, world production of carobs was estimated to about 310000 t/year produced at some 200000 ha with 
very variable yields depending on cultivar, region and farming practice (5).

Carob pods consist of two major parts: the pulp (80$90 \%$, by mass) and the seeds (10-20\%, by mass) (6). Both pulp and seeds can be used as feed or in food production in the form of flour (ground pods), or as locust bean gum (stabilizer, thickener) obtained from the endosperm of the carob seeds. It can also be used as a stabilizer or thickener in pharmaceutical and cosmetic industries $(5,7)$. After harvesting, carob pods are brought to a processing plant where they are dried to around $8 \%$ moisture to avoid rotting. Pods are then kibbled to separate pulp and seeds and ground depending on their final usage. In order to properly design the mechanization and the equipment for carob processing, physical and mechanical properties of carob are of great importance.

Mathematical modelling is often used to get an insight into process parameters that are very important in process design (8). Furthermore, it offers the possibility to minimize expenses for long-lasting studies that consume a lot of chemicals, energy, time, etc. In the case of carob, it is a well-known fact that pods are usually dried before their distribution to the market. The aim of this study is to shorten the drying time with the use of mathematical modelling to determine the most important drying parameters and the behaviour of the carob material during drying.

Furthermore, carob seeds are used in carob bean gum production (thickening agent). During production of locust bean gum, seeds are dehusked by treating the kernels with diluted sulfuric acid or with thermal mechanical treatment. Therefore, the aim is also to study the behaviour of the seeds in the drying process. Overall, the study aims to determine the difference in the behaviour of carob pods, pod sections and seeds during drying. Furthermore, textural properties, which play a significant role in carob processing, are also assessed. Differences in drying behaviour and texture will then be explained by micromorphologic characteristics of carob. Understanding these properties is of great importance in carob production and processing industry and can shorten or ease further steps (e.g. milling, sieving) in the industrial environment.

\section{Materials and Methods}

\section{Materials}

Carob (Ceratonia siliqua L.) pods were obtained from a local manufacturer from the island of Drvenik Mali,
Croatia. Population of carob trees on the island of Drvenik Mali belongs to the 'Komiža' carob ecotype, which is the most frequent carob ecotype spread on Croatian islands. To determine the morphological characteristics of carob pods and seeds before experiment, a sample of 120 carob pods was randomly selected from the lot. Measurements of their dimensions were carried out with a digital calliper (Mitutoyo, Kawasaki, Japan), and their mass was determined by a digital analytical balance (Mettler Toledo, Greifensee, Switzerland) with two decimal places (5). The geometric mean diameter $\left(d_{\mathrm{g}}\right)$ and sphericity $(\phi)$ of carob seeds were calculated using the following equations $(2,9)$ :

$$
\begin{aligned}
& d_{\mathrm{g}}=(l b \delta)^{1 / 3} \\
& \phi=\frac{(l b \delta)^{1 / 3}}{l}
\end{aligned}
$$

where $l$ is length, $b$ is width and $\delta$ is thickness in $\mathrm{mm}$.

Also, carob seed volume $(V)$ and surface area $(A)$ were calculated using the following equations $(2,10)$ :

$$
\begin{gathered}
V=\frac{\pi B^{2} l^{2}}{6(2 l-B)} \\
A=\frac{\pi B l^{2}}{2 l-B}
\end{gathered}
$$

where

$$
B=(b \delta)^{1 / 2}
$$

Morphological characteristics of raw carob material (pods and seeds, $N=120$ ) used in this study are shown in Table 1.

\section{Drying experiment}

Prior to drying, carob pod samples were prepared in the following manner: one carob pod was left intact, while the other was cut to obtain pod sections of approx. 2-3 $\mathrm{cm}$. Seeds were removed and also subjected to drying. Samples were weighed, placed in Petri dishes and dried on the top rack of the convection oven (Inkolab, Zagreb, Croatia) at $60^{\circ} \mathrm{C}$ for $6 \mathrm{~h}$, to assure the collection of enough experimental data for mathematical modelling. Oven dryer was equipped with a hot air circulation blower at air flow of $200 \mathrm{~m}^{3} / \mathrm{h}$, in order to ensure a uniform temperature gradient throughout the total volume of the drying chamber $(60 \mathrm{~L})$. An air exhaust was located on the top of the dryer to ensure migration of moisture outside the dry-

\begin{tabular}{|c|c|c|c|c|c|c|c|}
\hline Pod & & & & & & & \\
\hline$l / \mathrm{mm}$ & $b / \mathrm{mm}$ & $\delta / \mathrm{mm}$ & $\mathrm{m} / \mathrm{g}$ & $N$ & & & \\
\hline $176.50 \pm 0.15$ & $26.56 \pm 0.12$ & $7.57 \pm 0.08$ & $28.99 \pm 0.40$ & $10.98 \pm 0.17$ & & & \\
\hline \multicolumn{8}{|l|}{ Seeds } \\
\hline$l / \mathrm{mm}$ & $b / \mathrm{mm}$ & $\delta / \mathrm{mm}$ & $\mathrm{m} / \mathrm{g}$ & $d_{g} / \mathrm{mm}$ & $\phi$ & $V / \mathrm{mm}^{3}$ & $A / \mathrm{mm}^{2}$ \\
\hline $8.58 \pm 0.06$ & $6.76 \pm 0.06$ & $3.88 \pm 0.06$ & $0.18 \pm 0.01$ & 5.97 & $0.695 \pm 0.70$ & $83.87^{*}$ & $98.30^{*}$ \\
\hline
\end{tabular}
ing chamber. Relative humidity of the air inside the drying chamber was in the range from 20 to $25 \%$. In order to reduce the duration of drying, a higher temperature $(60$

Table 1. Characterization of morphological characteristics of carob (Ceratonia siliqua) pods and seeds used in the experiment ( $N=120)$

Results are expressed as mean value \pm standard deviation; ${ }^{*} \mathrm{~B}=5.12 \mathrm{~mm}$

$l=$ length, $b=$ width, $\delta=$ thickness, $m=$ mass, $d_{\mathrm{g}}=$ geometric mean diameter of seeds, $\phi=$ sphericity, $\mathrm{B}=$ coefficient used in volume $(V)$ and surface area $(A)$ calculations 
$\left.{ }^{\circ} \mathrm{C}\right)$ was used than in most carob drying procedures $(40$ $\left.{ }^{\circ} \mathrm{C}\right)$. Samples were collected in the interval of $30 \mathrm{~min}$ and weighed to obtain necessary data for further modelling. Initial moisture content was determined by drying at 105 ${ }^{\circ} \mathrm{C}$ for $4 \mathrm{~h}$, according to the standard AOAC method (11), while for equilibrium moisture content the sample was left to dry at the same temperature until no change in moisture was observed. Data retrieved from the experiments were further used for mathematical modelling.

\section{Mathematical modelling}

The moisture ratio during the drying experiments was calculated using the following equation:

$$
M R=\frac{w-w_{\mathrm{e}}}{w_{0}-w_{\mathrm{e}}}
$$

where $\mathrm{MR}$ is the dimensionless moisture ratio, $w$ is the moisture content measured at time $t, w_{0}$ is the initial moisture content and $w_{\mathrm{e}}$ is the equilibrium moisture content on dry mass basis.

Experimental drying data were then fitted to 11 different drying models shown in Table 2.

Table 2. Models used for experimental data fitting

\begin{tabular}{rlcc}
\hline No. & Model name & Equation & Reference \\
\hline 1 & Newton & $\mathrm{MR}=\mathrm{e}^{-\mathrm{kt}}$ & $(12,13)$ \\
2 & Henderson and Pabis & $\mathrm{MR}=\mathrm{a} \cdot \mathrm{e}^{-\mathrm{kt}}$ & $(14,15)$ \\
3 & Logarithmic & $\mathrm{MR}=\mathrm{a} \cdot \mathrm{e}^{-\mathrm{kt}}+\mathrm{c}$ & \\
4 & Two-term & $\mathrm{MR}=\mathrm{a} \cdot \mathrm{e}^{-\mathrm{kt}}+\mathrm{b} \cdot \mathrm{e}^{-\mathrm{k}_{0} \cdot \mathrm{t}}$ & $(12,15)$ \\
5 & Two term exponential & $\mathrm{MR}=\mathrm{a} \cdot \mathrm{e}^{-\mathrm{kt}}+(1-\mathrm{a}) \cdot \mathrm{e}^{-\mathrm{kat}}$ & $(16)$ \\
6 & Page & $\mathrm{MR}=\mathrm{e}^{-\mathrm{kt}}$ & $(12,15-17)$ \\
7 & Overhults & $\mathrm{MR}=\mathrm{e}^{-(\mathrm{kt})^{\mathrm{N}}}$ & $(12)$ \\
8 & Modified Page & $\mathrm{MR}=\mathrm{a} \cdot \mathrm{e}^{-\mathrm{kt} \mathrm{N}^{\mathrm{N}}}$ & $(12,15)$ \\
9 & Midilli-Kucuk & $\mathrm{MR}=\mathrm{a} \cdot \mathrm{e}^{-\mathrm{kt} \mathrm{t}^{\mathrm{N}}}+\mathrm{bt}$ & $(17)$ \\
10 & Wang and Singh & $\mathrm{MR}=1+\mathrm{a} t+\mathrm{b} t^{2}$ & $(15)$ \\
11 & Polynomial & $\mathrm{MR}=\mathrm{a} t^{2}+\mathrm{b} t+\mathrm{c}$ & $(18)$ \\
\hline
\end{tabular}

$\mathrm{MR}=$ moisture ratio, $\mathrm{a}, \mathrm{b}, \mathrm{c}$ and $\mathrm{N}=\mathrm{empirical}$ constants used in the drying models, $t=$ time $(\mathrm{min}), k=$ drying rate $\left(\mathrm{min}^{-1}\right)$

Non-linear regression was used to estimate the drying rate constants and coefficients. The suitability of a model was estimated and compared by coefficient of determination $\left(\mathrm{R}^{2}\right)$, mean percentage error (MPE) and root mean squared error (RMSE) (17), calculated according to the following equations:

$$
\begin{gathered}
\mathrm{MPE}=\frac{100}{N} \sum_{i=1}^{N} \frac{\left|\mathrm{MR}_{\mathrm{ex}, \mathrm{i}}-\mathrm{MR}_{\text {pred }, \mathrm{i}}\right|}{\mathrm{MR}_{\text {exp }, \mathrm{i}}} \\
\mathrm{RMSE}=\left[\frac{1}{N} \sum_{i=1}^{N}\left(\mathrm{MR}_{\mathrm{ex}, \mathrm{i}}-\mathrm{MR}_{\text {pred }, \mathrm{i}}\right)^{2}\right]^{1 / 2}
\end{gathered}
$$

where $\mathrm{MR}_{\mathrm{ex}, \mathrm{i}}$ is the $i$-th experimental dimensionless moisture ratio, $\mathrm{MR}_{\text {pred,i }}$ is the $i$-th predicted moisture ratio and $N$ is the number of measurements.
Furthermore, drying rates were calculated from the drying data by estimating the change in the moisture content that occurred in each consecutive time interval (19). Drying rate was expressed in $g$ of water per g of dry matter per min.

Model fitting, probability and error calculations were performed using STATISTICA v. 10.0 (StatSoft, Tulsa, OK, USA) and Excel (Microsoft, Redmond, WA, USA) software.

\section{Effective diffusivity coefficient}

In the drying period in which the drying rate is falling, internal resistance governs the mass transfer. Fick's law can be used to calculate the effective drying coefficients (17). Experimental drying data in terms of $\ln (\mathrm{MR})$ were plotted in correlation with drying time. Linear slope is defined according to Akgun and Doymaz (20) as follows:

$$
\text { Slope }=\frac{\pi^{2} D_{\text {eff }}}{4 L^{2}}
$$

where $D_{\text {eff }}$ represents the effective diffusivity coefficient $\left(\mathrm{m}^{2} / \mathrm{s}\right)$ and $L$ is half the thickness of the pod, pod parts and seeds $(\mathrm{m})$ used in the experiment.

\section{Texture measurements}

Texture measurements were done using TA.HDPlus Texture Analyser (Stable Micro Systems, Godalming, UK) equipped with a 750-kg load cell. As specific parts of the tested samples had moderately uniform surface, flat bottom stainless steel cylinder probe with a $20-\mathrm{mm}$ radius (P/40; Stable Micro Systems) was used. Modified single-point compression test during single cycle was used for analysis. Pre-test and test speed were set to $0.5 \mathrm{~mm} / \mathrm{s}$. Using only single-cycle measurements, post-test speed was set to $100 \mathrm{~mm} / \mathrm{s}$. Maximum compression depth was set at $2.0 \mathrm{~mm}$ for instrument and probe safety, with target mode set at $60 \%$ strain, as higher strains were shown to be too destructive for precise analysis. To ensure timely start of measuring of mechanical properties, trigger force was set to $3.0 \mathrm{~g}$. Changes in compression force (in $\mathrm{N}$ ) during measurement were recorded. Before measurements, all samples were tempered at room temperature of $(25 \pm 0.5)$ ${ }^{\circ} \mathrm{C}$. Because of the morphological differences in the carob pod structure, three zones were selected for measurements, as shown in Fig. 1. Seeds were compressed along the horizontal axis. All measurements were repeated five times and the results were expressed as mean value \pm standard deviation.

\section{Micromorphological studies}

Micrographic analysis was performed using a binocular magnifier Carl Zeiss Stemi 2000-C at 2× magnification and a binocular microscope Carl Zeiss Axiolab with normal and phase contrast (Ph2) objective (Carl Zeiss Microscopy, Jena, Germany) at 4 and $40 \times$ magnifications.

Samples were prepared with a scalpel, making the cross-sections of three different zones of the carob pods near the tip of the pod, at the centre and near the base (stem), which were the same areas used in texture analysis shown in Fig. 1. Microphotographs of cross-sections of 


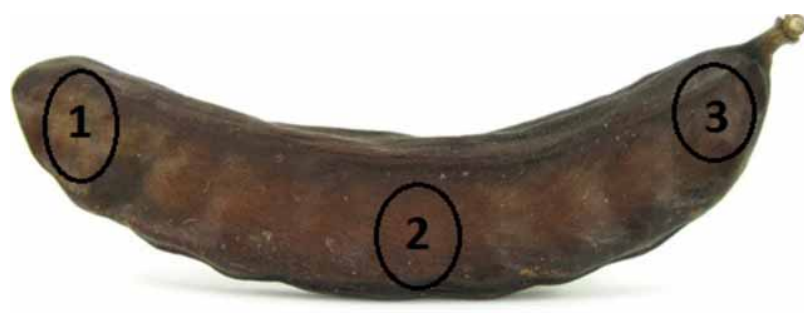

Fig. 1. Compression zones selected for texture measurements of carob pod

the carob seed were also recorded. All the microphotographs were taken with Dino-Eye eyepiece camera, driven by DinoCapture v. 2.0 software (AnMo Electronics Corporation, Hsinchu, Taiwan).

\section{Results and Discussion}

\section{Drying of carob pods and seeds}

The initial moisture content on dry mass basis of carob pods was $0.0535 \mathrm{~g} / \mathrm{g}$, of pod parts $0.0648 \mathrm{~g} / \mathrm{g}$ and seeds $0.0730 \mathrm{~g} / \mathrm{g}$. These data showed that the sum of the initial moisture contents of the pulp and the seeds, as the constituents of the pod, exceeded the total moisture content of the whole, intact carob pod. Similar results were obtained previously by Avallone et al. (21). The reason for this lies in the structure of the carob pod, which contains an outer leathery layer (tunica), which, when intact, prevents moisture migration outside of the pod, making it ideal for cultivation and survival in warm and dry Mediterranean regions (5).

Drying curves of the carob pod, pod parts and seeds at $60^{\circ} \mathrm{C}$, visualized as a comparison between experimental and model-predicted data, are shown in Fig. 2.

Drying curves in Fig. 2 are presented as a dependence of a dimensionless moisture ratio to drying time.
Three different curves for three different carob samples prepared in a different manner are visible. In the whole carob pod, moisture ratio dropped from the initial value of 1 to 0.46 , which represented the smallest difference in moisture ratio after $360 \mathrm{~min}$ of drying in comparison with pod parts and seed. Moisture ratio of pod parts decreased to 0.45 after $360 \mathrm{~min}$ of drying, while the carob seeds showed the highest decrease in moisture ratio - from initial 1 to the final 0.07. Based on these drying curves, it was clear that intact carob pod lost moisture at a smaller rate than sliced pod parts and seeds. It was also visible that the moisture content decreased continuously with drying time, which is a characteristic of thin samples (17).

\section{Mathematical modelling of experimental drying data}

In order to calculate the drying rate of the samples and confirm the observations from the drying curves, experimental data were fitted to 11 different mathematical models. The appropriate model for description of carob drying was then selected based on $R^{2}$, MPE and RMSE values. Results are shown in Table 3.

Based on the $\mathrm{R}^{2}$ values in Table 2, drying models exhibited good fit to experimental data. The lowest fit was obtained for the Newton model $\left(R^{2}=0.9697\right)$ and the best for the empirical Midilli-Kucuk model $\left(\mathrm{R}^{2}=0.9999\right)$. Mean percentage error (MPE) for carob fruit drying ranged from $0.1712 \%$ for Midilli-Kucuk to $4.8882 \%$ for the Newton model. According to the literature data, MPE lower than $10 \%$ is considered appropriate for experimental data modelling $(16,22)$. Values obtained by mathematical modelling for carob pod drying were lower than $10 \%$ for all models. Root mean squared error (RMSE) was the lowest for three models: logarithmic, Midilli-Kucuk and polynomial. However, based on the combination of the values of all three statistical parameters, Midilli-Kucuk model was chosen as the most suitable one. Values of the Midilli-Kucuk model obtained for carob pods were $\mathrm{a}=1.0001$, $k=0.0166 \mathrm{~s}^{-1}, \mathrm{~N}=0.6156$ and $\mathrm{b}=-0.0002$, as shown in Table 2 .

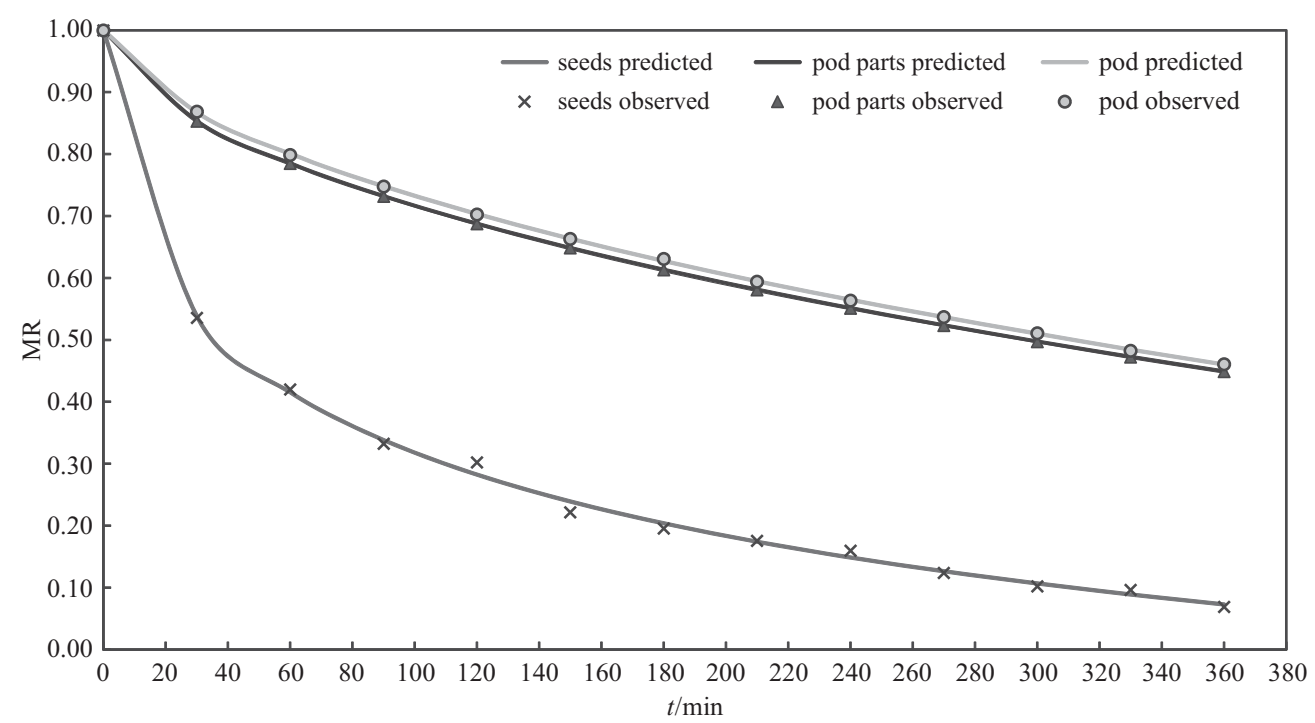

Fig. 2. Drying curves of carob seeds, pod parts and whole carob pod. Data are shown as comparison between experimentally observed and the data predicted by the model. $M R=$ moisture ratio 
Table 3. Estimated values of coefficient of determination $\left(\mathrm{R}^{2}\right)$, mean percentage error (MPE) and root mean squared error (RMSE)

\begin{tabular}{|c|c|c|c|c|c|}
\hline Sample & Model name & Estimated value & $\mathrm{R}^{2}$ & $\mathrm{MPE} / \%$ & RMSE \\
\hline \multirow{11}{*}{ Carob pod } & Newton & $k=0.0024$ & 0.9697 & 4.8882 & 0.0416 \\
\hline & Henderson and Pabis & $\mathrm{a}=0.9353 ; k=0.0021$ & 0.9876 & 2.7188 & 0.0017 \\
\hline & Logarithmic & $\mathrm{a}=0.5962 ; k=0.0050 ; \mathrm{c}=0.3777$ & 0.9964 & 1.6047 & 0.0000 \\
\hline & Two-term & $\mathrm{a}=0.8974 ; k=0.0019 ; \mathrm{b}=0.1026 ; k_{0}=14.0000$ & 0.9984 & 1.0681 & 0.0004 \\
\hline & Two-term exponential & $\mathrm{a}=0.1079 ; k=0.0179$ & 0.9937 & 1.9928 & 0.0221 \\
\hline & Page & $k=0.0126 ; \mathrm{N}=0.6977$ & 0.9997 & 0.4525 & 0.0008 \\
\hline & Overhults & $k=0.0019 ; \mathrm{N}=0.6977$ & 0.9997 & 0.4525 & 0.0008 \\
\hline & Modified Page & $\mathrm{a}=0.9974 ; k=0.0122 ; \mathrm{N}=0.7025$ & 0.9997 & 0.4539 & 0.0001 \\
\hline & Midilli-Kucuk & $\mathrm{a}=1.0001 ; k=0.0166 ; \mathrm{N}=0.6156 ; \mathrm{b}=-0.0002$ & 0.9999 & 0.1712 & 0.0000 \\
\hline & Wang and Singh & $a=-0.0028 ; b=4 \cdot 10^{-6}$ & 0.9880 & 2.9679 & 0.0225 \\
\hline & Polynomial & $a=3 \cdot 10^{-6} ; b=-0.0002 ; c=0.9580$ & 0.9935 & 2.0799 & 0.0000 \\
\hline \multirow{11}{*}{ Pod parts } & Newton & $k=0.0025$ & 0.9610 & 5.6750 & 0.0467 \\
\hline & Henderson and Pabis & $\mathrm{a}=0.9255 ; k=0.0022$ & 0.9840 & 3.1289 & 0.0020 \\
\hline & Logarithmic & $\mathrm{a}=0.5842 ; k=0.0055 ; \mathrm{c}=0.3859$ & 0.9950 & 1.8392 & 0.0000 \\
\hline & Two-term & $\mathrm{a}=0.8814 ; k=0.0019 ; \mathrm{b}=0.1186 ; k_{0}=18.0000$ & 0.9980 & 1.1227 & 0.0005 \\
\hline & Two-term exponential & $\mathrm{a}=0.1106 ; k=0.0185$ & 0.9900 & 2.7062 & 0.0217 \\
\hline & Page & $k=0.0155 ; \mathrm{N}=0.6670$ & 0.9970 & 0.4980 & 0.0009 \\
\hline & Overhults & $k=0.0019 ; \mathrm{N}=0.6670$ & 0.9997 & 0.4980 & 0.0009 \\
\hline & Modified Page & $\mathrm{a}=0.9971 ; k=0.0150 ; \mathrm{N}=0.6720$ & 0.9997 & 0.4988 & 0.0001 \\
\hline & Midilli-Kucuk & $\mathrm{a}=1.0000 ; k=0.0210 ; \mathrm{N}=0.5789 ; \mathrm{b}=-0.0002$ & 0.9999 & 0.0902 & 0.0000 \\
\hline & Wang and Singh & $a=-0.0076 ; b=0.0002$ & 0.8060 & 34.1673 & 0.5107 \\
\hline & Polynomial & $a=3 \cdot 10^{-6} ; b=-0.0025 ; c=0.9509$ & 0.9915 & 2.3686 & 0.0000 \\
\hline \multirow{11}{*}{ Carob seed } & Newton & $k=0.0108$ & 0.9620 & 36.3996 & 0.0486 \\
\hline & Henderson and Pabis & $\mathrm{a}=0.8671 ; k=0.0090$ & 0.9470 & 26.3954 & 0.0549 \\
\hline & Logarithmic & $\mathrm{a}=0.8304 ; k=0.0161 ; \mathrm{c}=0.1211$ & 0.9470 & 36.3948 & 0.0485 \\
\hline & Two-term & $\mathrm{a}=0.6183 ; k=0.0062 ; \mathrm{b}=0.3817 ; k_{0}=15.0000$ & 0.9850 & 19.1390 & 0.0000 \\
\hline & Two-term exponential & $\mathrm{a}=0.2254 ; k=0.0378$ & 0.9980 & 5.4908 & 0.0043 \\
\hline & Page & $k=0.0100 ; \mathrm{N}=05650$ & 0.9750 & 24.3126 & 0.0249 \\
\hline & Overhults & $k=0.0132 ; \mathrm{N}=0.5645$ & 0.9980 & 6.1095 & 0.0034 \\
\hline & Modified Page & $\mathrm{a}=0.8671 ; k=0.0029 ; \mathrm{N}=3.1617$ & 0.9620 & 26.3809 & 0.0547 \\
\hline & Midilli-Kucuk & $\mathrm{a}=0.9999 ; k=0.1162 ; \mathrm{N}=0.4877 ; \mathrm{b}=-0.0002$ & 0.9990 & 3.8202 & 0.0000 \\
\hline & Wang and Singh & $a=-0.0073 ; b=1.4 \cdot 10^{-5}$ & 0.8890 & 43.6321 & 0.1069 \\
\hline & Polynomial & $a=9 \cdot 10^{-6} ; b=-0.0052 ; c=0.8010$ & 0.9430 & 26.8412 & 0.0000 \\
\hline
\end{tabular}

$\mathrm{a}, \mathrm{b}, \mathrm{c}$ and $\mathrm{N}=\mathrm{empirical}$ constants used in drying models, $k$ and $k_{0}=\mathrm{drying}$ rates at time $t$ and $t=0$, respectively $\left(\min ^{-1}\right)$

The Midilli-Kucuk model was also chosen as the most appropriate for modelling of the drying of carob pod parts, due to the highest $R^{2}$ value (0.9999). Values estimated for Midilli-Kucuk model for pod part drying were $\mathrm{a}=1.0000$, $k=0.0210 \mathrm{~min}^{-1}, \mathrm{~N}=0.5879$ and $\mathrm{b}=-0.0002$. The lowest fit was detected for the Wang and Singh model. This model exhibited high mean percentage error (MPE=34.1673\%), making it unsuitable for further consideration.

Most of the estimated drying models proved to be inadequate for carob seed drying, due to high MPE. Two-term exponential, Overhults and the Midilli-Kucuk were the only three models that had MPE lower than $10 \%$. In this case, the Midilli-Kucuk model was the most suitable due to the highest $R^{2}$ value $\left(R^{2}=0.9990\right)$ and the lowest MPE (3.8202 \%) and RMSE (0.0000). Parameters estimated for this model were $\mathrm{a}=0.9999, k=0.1162 \mathrm{~min}^{-1}, \mathrm{~N}=0.4877$ and $\mathrm{b}=-0.0002$.
In direct comparison of the estimated parameters for whole pods, pod parts and seeds, differences were visible between $k$ and $\mathrm{N}$ values. The highest drying rate $\left(k / \mathrm{min}^{-1}\right)$ was detected of carob seeds, followed by carob pulp and carob pods, which was in accordance with the obtained drying curves. Due to a higher drying rate of seeds and pod parts, sum of the initial moisture content of seeds and pod parts appeared to be higher than that of the whole, intact pod, for which a lower drying rate was detected.

Based on the model selected as the most appropriate for carob drying, drying rates were calculated from the drying data by estimating the change in moisture content which occurred in each consecutive time interval.

According to the data presented in Fig. 3, the drying rate decreased with a decrease in moisture content. Higher drying rates correspond to the beginning of the drying process, when more moisture was still present in the sam- 


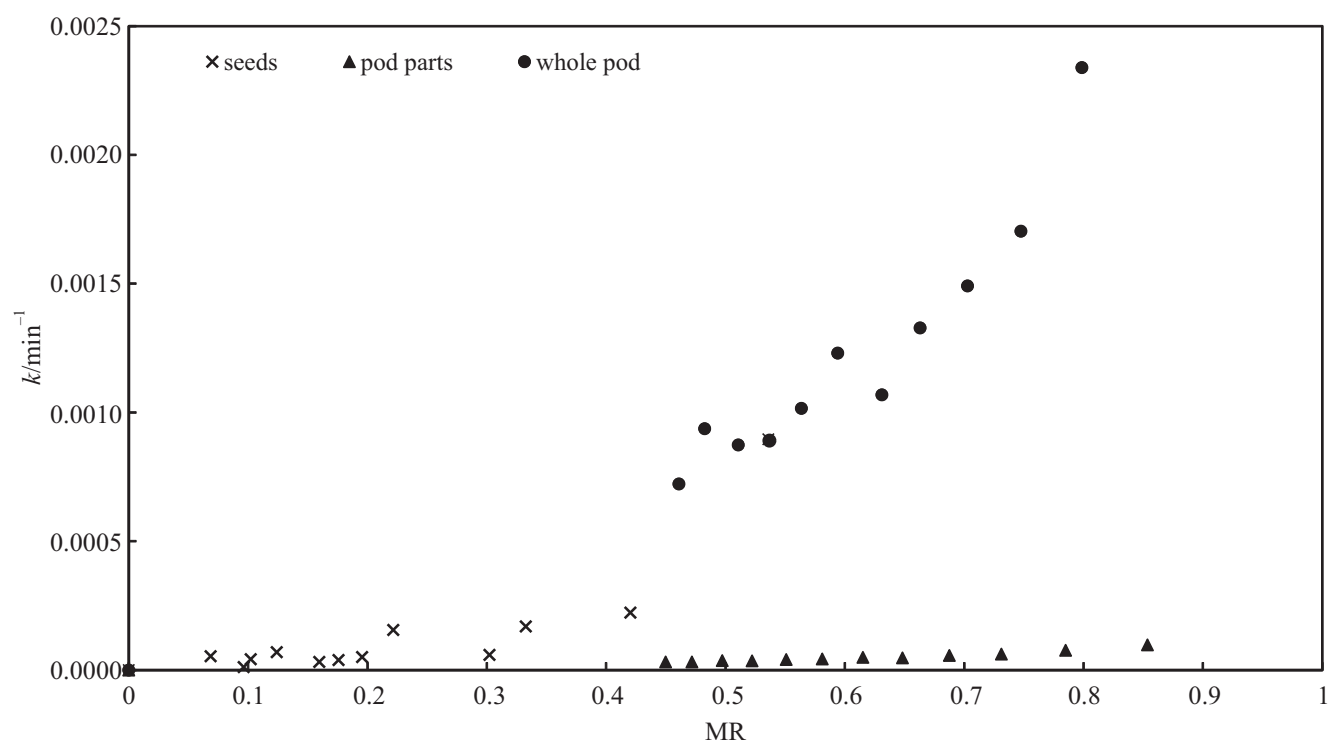

Fig. 3. Drying rates of carob pods, pod parts and seeds. MR=moisture ratio, $k=$ drying rate

ple. Similar drying curves were also detected for bay laurel drying process (17). This can be explained in two ways. First, by evaporation of water from the surface of the pod, which is less likely since the protective layer contains very little water. Second, it has been implicated (19) that the accelerated drying rates can be attributed to internal heat generation, which is a much more plausible explanation, based on the structure of the carob pod. Furthermore, a rise in the drying rate is not as emphasized for the pod parts and seeds as for the whole pod, which contributes to the latter explanation. Overall, the drying rate of all the tested samples appears to be slow.

\section{Effective diffusivity coefficients of carob pods, parts and seeds}

Effective diffusivity coefficients calculated from the slope of $\ln (\mathrm{MR})$ vs. drying time were: $1.627 \cdot 10^{-9} \mathrm{~m}^{2} / \mathrm{s}$ for seeds, $2.226 \cdot 10^{-10} \mathrm{~m}^{2} / \mathrm{s}$ for whole pods and $2.322 \cdot 10^{-10} \mathrm{~m}^{2} / \mathrm{s}$ for sliced pod parts. Based on these values, moisture diffusion from all of the samples is very slow. Seeds are more prone to moisture migration than pod parts and pods. These values can be compared to diffusion coefficients calculated for corn (23) and garlic slices (24).

\section{Texture of carob fruit and seeds}

Based on morphological analysis, carob pods are sickle shaped, 10-20 cm long, 2-4 cm wide and contain 10-15 oval shaped seeds (25). These numbers vary significantly depending on the variety, climate conditions and genetic resources (26). Length and width of the fruit, number and distribution of the seeds in the pod and the location of the testing area on the pod all affect the results of carob texture and compression analysis (1). Three different compression testing zones were selected on carob pods in this research (Fig. 1): near the tip of the fruit (area 1 ), at the centre (area 2) and near the stem (area 3). Maximum compression forces of the seeds were also determined. Results are shown in Table 4.
Table 4. Maximum compression forces $\left(F_{\max }\right)$ of carob fruit and seeds

\begin{tabular}{lc}
\hline Sample & $F_{\max } / \mathrm{N}$ \\
\hline Carob pod (whole) & \\
Area 1 & $21.7 \pm 1.7$ \\
Area 2 & $13.5 \pm 1.1$ \\
Area 3 & $30.1 \pm 2.8$ \\
Carob seed & $3092.1 \pm 430.2$ \\
\hline
\end{tabular}

Results are expressed as mean value \pm standard deviation

As shown in Table 4, maximum compression force of carob fruit ranged from 13.5 to $30.1 \mathrm{~N}$. Also, these values varied according to the position on the fruit where the test was performed. The highest compression force was obtained in area 3, followed by area 1 and area 2. Based on morphological assessment, these differences could be explained by an uneven distribution of the seeds in the centre, tip and near the stem, and the differences in the thickness of the carob fruit in these positions. Furthermore, they will also be explained by micrographic images in the following section. Maximum compression force of the seeds was higher than of carob fruit. Seeds are known to be very hard due to the presence of the top coat (2), which serves for seed protection. Some researchers have also considered the cracking force of the seeds, and concluded that it depends on the position of the seed during testing (loading on vertical or horizontal axis or thickness), and is the highest on vertical axis (27).

\section{Micromorphological traits of carob pods and seeds}

Fig. 4a shows a cross-section of the carob fruit, with visible tissue layers. The upper, dark coloured layer is the tunica or the envelope of the pod, with the mechanical tissue and pulp below. Tunica cells were further studied in Fig. $4 \mathrm{~b}$, showing a cross-section taken at about $4 \mathrm{~mm}$ distance from the stem. The top part represents a monolayer 
epidermis followed by mesoderm layer containing mechanical cells with thickened cell walls. Inside the mesoderm, dead cells (sclerenchyma) were also present. At the bottom of the mechanical tissue, the main nerve is visible with collenchyma cells surrounding it. Considering the structures of mechanical tissue, it was obvious that this layer served as a protector of the inner parts of the pod, which caused an increase of force required to compress such a tissue, and which was in accordance with the high- est compression force detected in this zone (zone 3) during texture analysis. Cross-section through the carob pod tip is shown in Fig. 4c. It was visible that there were no nerves present in this area and that the layer of mechanical tissue was much thinner, which was the reason why lower compression force was detected in this zone (area 1), than in the stem part (area 3). Mechanical tissue present in the tunica was further studied at a greater magnification with the phase contrast objective (Fig. 4d).
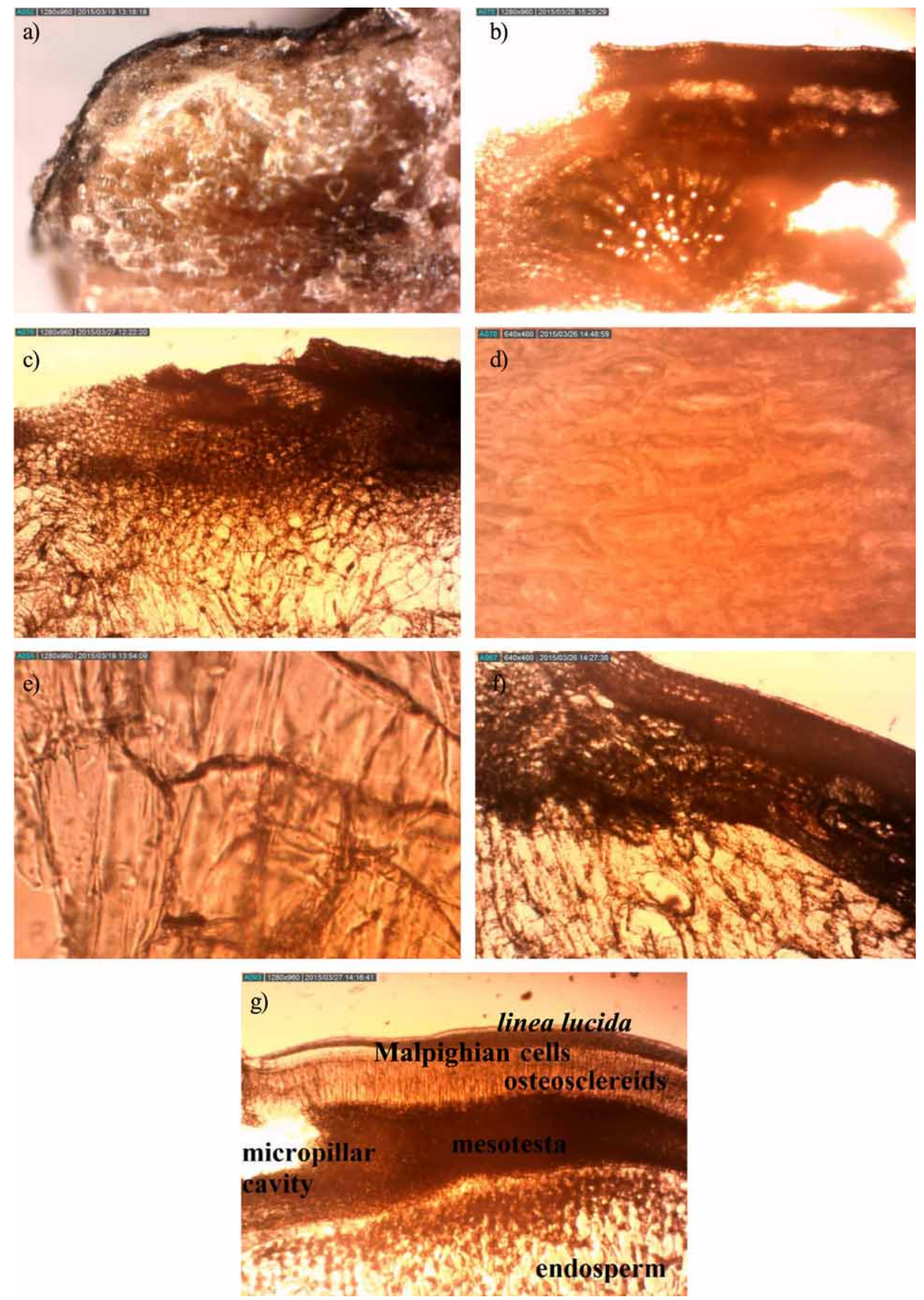

Fig. 4. Cross-sections of carob pods and seeds: a) cross-section of the centre of carob pod, taken by a binocular magnifier Carl Zeiss at 2× magnification, $b$ ) cross-section through the tunica of the carob pod taken near the stem with completely visible main nerve and mechanical tissue (Carl Zeiss Axiolab microscope, $4 \times$ magnification), c) cross-section of the tip of the carob pod (Carl Zeiss Axiolab microscope, $4 \times$ magnification), d) mechanical tissue cells of sclerenchyma with very strong and wide cell walls (Carl Zeiss Axiolab microscope, phase contrast objective at $40 \times$ magnification), e) parenchymal tissue of the carob pod (Carl Zeiss Axiolab microscope, phase contrast objective at 40× magnification), f) mechanical tissue and parenchyma of pulp located in the central/inner zone of carob pod (Carl Zeiss Axiolab microscope, $4 \times$ magnification), and g) cross-section of the carob seed (binocular magnifier Carl Zeiss, $4 \times$ magnification) 
These cells had wide and hardened cell walls, which act as a barrier for moisture migration outside the carob fruit. The moisture migration through hardened, wide cell walls was difficult, resulting in the lowest drying rate of whole, intact carob pod. Parenchyma cells of the carob pod pulp were larger than the mechanical cells and had thinner cell walls, as shown in Fig. 4e. The cross-section of the central part of carob pod is shown in Fig. 4f. The mechanical layer which forms the mesoderm was thinner and the mechanical cells were larger. A seam which was once part of the ovary in the carpel is also visible. This was the part with the lowest mechanical strength and the zone in which the lowest compression forces were detected in texture analysis (area 2). Seed cross-section is shown in Fig. 4g. The outer envelope of the seed, seen in the top of the image, consisted of a monolayer epidermis. Then followed a layer of linea lucida tissue, and a layer of hollow cells, called Malpighian cells, oriented around an imaginary vertical line. Two more layers of the mechanical tissue of osteosclereids and mesotesta, and finally parenchymatous cells of endosperm are visible (directed to the centre of microphotograph) $(28,29)$. This cavity was the cause of the highest drying rate of the seeds. Namely, it is obvious in Fig. $4 \mathrm{~g}$ that the layers of seed coat are the thinnest around the micropillar cavity. On the other hand, the coat layers further from the seed become thicker. According to the results of our microscopic studies of carob seed structure, it is possible that the water evaporates from endosperm through micropillar cavity, and also through the undifferentiated layers of Malpighian cells and linea luc$i d a$ out of the carob seed. This is more likely than evaporation through the thicker layers of seed coat (seed testa), primarily considering the structure of mesotesta, which belongs exclusively to mechanical tissue with very hard cell walls. Such microstructure of carob seeds also causes very high mechanical resistance. On the other hand, considering the morphology and anatomy of carob pods (Figs. 4a, b and f), the continuous layer of mechanical tissue primarily represented by sclerenchyma is clearly visible, with sporadic nests of collenchyma around the vessels of carob pod (Fig. 4b). Thus, evaporation of water certainly takes place through the xylem of the carob pod vessels, more likely than directly through the layer of mechanical pod tissue. This can be explained with the structure of mechanical tissue of the pods. Fig. $4 \mathrm{~d}$ shows that there is no intercellular space between the cells of sclerenchyma and, moreover, the cell walls are very thick in comparison with cell lumen. However, the thickness of mechanical tissue layer is not equal at the pedicel and at the end of carob pod, which completely corresponds to the differences in mechanical resistance, measured in different locations on carob pod.

\section{Conclusions}

Carob pods were studied in order to determine their drying characteristics, texture and micromorphological traits. During drying, moisture content of whole pods, pod parts and seeds decreased constantly with drying time, exhibiting a behaviour characteristic for thin samples. Mathematical modelling of the data obtained by the drying experiments defined the Midilli-Kucuk empirical model as the most suitable for description of the drying process. Based on the values obtained from the mathematical models, the highest drying rate was detected in carob seeds $\left(k=0.1162 \mathrm{~min}^{-1}\right)$, followed by parts of carob pods $\left(k=0.0210 \mathrm{~min}^{-1}\right)$ and carob pods $\left(k=0.0166 \mathrm{~min}^{-1}\right)$. The seeds exhibited the highest compression force, followed by the stem zone, the tip and the centre of the fruit. Drying experiment results, as well as the texture study results, can all be explained by the differences in microstructures of given parts of the carob pod.

\section{Acknowledgement}

This research was funded by Croatian Science Foundation, grant number: IP-11-2013-3304-TEUCLIC.

\section{References}

1. Ekinci K, Yilmaz D, Ertekin C. Effects of moisture content and compression positions on mechanical properties of carob pod (Ceratonia siliqua L.). Afr J Agric Res. 2010;5:101521.

http://dx.doi.org/10.5897/AJAR09.179

2. Karababa E, Coşkuner Y. Physical properties of carob bean (Ceratonia siliqua L.): an industrial gum yielding crop. Ind Crops Prod. 2013;42:440-6. http://dx.doi.org/10.1016/j.indcrop.2012.05.006

3. Akbulut S, Bayramoglu MM. The trade and use of some medicinal and aromatic herbs in Turkey. Ethno Med. 2013;7: 67-77.

4. Rababah TM, Al-u'datt M, Ereifej K, Almajwal A, Al-Mahasneh $\mathrm{M}$, Brewer $\mathrm{S}$, et al. Chemical, functional and sensory properties of carob juice. J Food Qual. 2013;36:238-44. http://dx.doi.org/10.1111/jfq.12033

5. Batlle I, Tous J. Carob tree. Ceratonia siliqua L. Promoting the conservation and use of underutilized and neglected crops. 17. Rome, Italy: International Plant Genetic Resources Institute; 1997.

6. Oziyci HR, Tetik N, Turhan I, Yatmaz E, Ucgun K, Akgul H, et al. Mineral composition of pods and seeds of wild and grafted carob (Ceratonia siliqua L.) fruits. Sci Hortic. 2014; 167:149-52.

http://dx.doi.org/10.1016/j.scienta.2014.01.005.

7. Durazzo A, Turfani V, Narducci V, Azzini E, Maiani G, Carcea M. Nutritional characterisation and bioactive components of commercial carob flours. Food Chem. 2014;153:10913.

http://dx.doi.org/10.1016/j.foodchem.2013.12.045

8. Angira R, Babu BV. Optimization of process synthesis and design problems: a modified differential evolution approach. Chem Eng Sci. 2006;61:4707-21. http://dx.doi.org/10.1016/j.ces.2006.03.004

9. Mohsenin NN. Physical properties of plant and animal materials. New York, NY, USA: Gordon and Breach Science Publishers Inc.; 1980. pp. 51-87.

10. Jain RK, Bal S. Properties of pearl millet. J Agric Eng Res. 1997;66:85-91. http://dx.doi.org/10.1006/jaer.1996.0119

11. AOAC Official Methods of Analysis. Determination of moisture content. Rockville, MD, USA: AOAC International; 1990.

12. Zhang $Y$, Chen $H$, Chen T. Drying kinetics of RDX under atmospheric pressure and vacuum conditions. Energ Convers Manage. 2014;80:266-75. http://dx.doi.org/10.1016/j.enconman.2014.01.039

13. Kaleta A, Górnicki K, Winiczenko R, Chojnacka A. Evaluation of drying models of apple (var. Ligol) dried in a fluid- 
ized bed dryer. Energ Convers Manage. 2013;67:179-85. http://dx.doi.org/10.1016/j.enconman.2012.11.011

14. Roberts JS, Kidd DR, Padilla-Zakour O. Drying kinetics of grape seeds. J Food Eng. 2008;89:460-5.

http://dx.doi.org/10.1016/j.jfoodeng.2008.05.030

15. Akpinar EK. Drying of mint leaves in a solar dryer and under open sun: modelling, performance analyses. Energ Convers Manage. 2010;51:2407-18. http://dx.doi.org/10.1016/j.enconman.2010.05.005

16. Corrêa PC, Botelho FM, Oliveira GHH, Goneli ALD, Resende O, Campos SC. Mathematical modeling of the drying process of corn ears. Acta Sci Agron. 2011;33:575-81. http://dx.doi.org/10.4025/actasciagron.v33i4.7079

17. Yurtlu YB. Drying characteristics of bay laurel (Laurus nobilis L.) fruits in a convective hot-air dryer. Afr J Biotechnol. 2011;10:9593-9. http://dx.doi.org/10.5897/AJB11.713

18. Krička T, Jukić Ž, Voća N, Miletić S. Drying comparative analysis of the rape seeds of $» 00$ « variety silvia and of $» 00$ « varieties Diana, Karola, Semu 910201, Semu 93-10 and Lirajet. Agric Conspec Sci 1999;64:113-21 (in Croatian).

19. Pathare PB, Sharma GP. Effective moisture diffusivity of onion slices undergoing infrared convective drying. Biosyst Eng. 2006;68:455-61.

http://dx.doi.org/10.1016/j.biosystemseng.2005.12.010

20. Akgun NA, Doymaz I. Modelling of olive cake thin-layer drying process. J Food Eng. 2005;68:455-61. http://dx.doi.org/10.1016/j.jfoodeng.2004.06.023
21. Avallone R, Plessi M, Baraldi M, Monzani A. Determination of chemical composition of carob (Ceratonia siliqua): protein, fat, carbohydrates, and tanins. J Food Comp Anal. 1997;10: 166-72. http://dx.doi.org/10.1006/jfca.1997.0528

22. Mohapatra D, Rao PS. A thin layer drying model of parboiled wheat. J Food Eng. 2005;66:513-8. http://dx.doi.org/10.1016/j.jfoodeng.2004.04.023

23. Doymaz I, Pala M. The thin-layer drying characteristics of corn. J Food Eng. 2003;60:125-30. http://dx.doi.org/10.1016/S0260-8774(03)00025-6

24. Madamba PS, Driscoll RH, Buckle KA. The thin-layer drying characteristics of garlic slices. J Food Eng.1996;29:75-97. http://dx.doi.org/10.1016/0260-8774(95)00062-3

25. Barak S, Mudgil D. Locust bean gum: processing, properties and food applications - a review. Int J Biol Macromol. 2014; 66:74-80.

http://dx.doi.org/10.1016/j.ijbiomac.2014.02.017

26. Tetik N, Turhan I, Oziyci HR, Gubbuk H, Karhan M, Ercisli S. Physical and chemical characterization of Ceratonia siliqua L. germplasm in Turkey. Sci Hortic. 2011;129:583-9. http://dx.doi.org/10.1016/j.scienta.2011.04.029

27. Ogunjimi LAO, Aviara NA, Aregbesola OA. Some engineering properties of locust bean seed. J Food Eng. 2002;55:95-9. http://dx.doi.org/10.1016/S0260-8774(02)00021-3

28. Black M, Bewley DJ, Halmer P. The encyclopedia of seeds: science, technology and uses. Wallingford, UK: CABI; 2006.

29. Fahn A. Plant anatomy. Oxford, UK: Pergamon Press; 1990. 